\title{
Study of Factors Leading To Employee Turnover across Different Industries with Special Emphasis on Banks-A Detailed Literature Review
}

\author{
Dr. Anjali Kalse ${ }^{1} \&$ Ruchika Goel ${ }^{2}$ \\ 1(Professor and Research Guide at Bharti Vidyapeeth Institute of Management Studies \& Research, Navi \\ Mumbai, India) \\ ${ }^{2}$ (Assistant Professor at Pillai Institute Of Management Studies and Research, Navi Mumbai, India)
}

\begin{abstract}
Labour turnover was studied on various factors like-customer complaints and satisfaction, personal growth, achievement, self control, compensation or monetary growth, self actualization, work motivation, social affiliation, organizational climate, culture clash, availability of better jobs, stress, burnout, job embeddedness, job characteristic, transactional leadership, business cycle, affective organizational commitment, quality of work life, non financial gains, career growth, working hours, family reasons, welfare, working conditions, position requirement challenge, lack of advancement etc across different industries like Banks, nursing,education, IT and ITES,manufacturing, retail, medical in different countries like India, Malaysia, USA,Ghana, Nigeria, Netherlands and Denmark.It was found that not much research is carried in this area and specially HR policy is almost untouched which plays a vital role on employee retention. A study of five reports and twenty one research papers was done from 2001 to 2014.
\end{abstract}

Key words: employee turnover, attrition, retention,banks, performance, organizational commitment,HR practices.

\section{Introduction}

India is one of the top 10 economies globally and has vast potential for the banking and finance sector .The other developing economies shows an average of $41 \%$ population having bank accounts in comparison to India with only $35 \%$ of tapped market which is leading to surge in banking activity in India. India's banking sector has the potential to become the fifth largest banking sector globally by 2020 and the third largest by 2025 . The Indian government's role in expanding the banking industry has been significant. Government is issuing new bank licenses to promote banks in India, with the move of financial inclusion more branches are opening up .recently government has given licence to two NBFCs -Infrastructure Development Finance Company (IDFC) and Bandhan Financial Services Pvt Ltd have been chosen among a field of 25 banks by the RBI to set up banks.Jammu and Kashmir (J\&K) Bank is looking at opportunities to increase its presence outside the country. The bank is likely to establish branches in London and Dubai to strengthen its relationships with current customers who have business interests in Europe and West Asia. In order to meet the growing competition banks are turning their focus to servicing clients. Banks in the country, including those in the public sector, are emphasising on enhancing their technology infrastructure, in order to improve customer experience and gain a competitive edge. Banks are also looking at new ways to attract customers. In September, 2013, ICICI bank leveraged the popularity of the social platform, and launched its Face book banking service, Pockets. The service enables customers to transfer funds and pay bills from within the website. In India, the banking setup is divided into four main categories-

1. Scheduled banks in Indian public sector- It has 26 members*

2. Scheduled banks in Indian private sector- Number of members are- $10^{*}$

3. Scheduled foreign banks in India- Number of members are $-12 *$

4. Scheduled Co-operative banks in India-Number of members are-53*

Data is as per the year 2012.Some new names are added in the list later which is not counted.

\section{Need Of The Study}

According to Hay group study, one in four employees in India is ready to switch the job with India topping the list globally. The attrition was highest $26.9 \%$ in 2013 in India. The attrition was triggered due to job opportunities increasing in many organized sectors. The most turmoiled sectors are banking and infrastructure. The surge is due to new banks coming and untapped market in India. [1]

According to PTI report nearly twenty lakh jobs would be created in 5 years in banking Industry due to issuance of new licenses. Not only banking but related areas like IT, ITES, infrastructure, telecom which are helping banking industry as support functions would also witness an increase in hiring. [2] 
Another factor which is catalysing banking recruitments is high rate of retirements in PSU banks, According to Mc Kinsey's report, around 60-90\% of PSU bank employees at DGM and GM levels may retire by 2016-17 and it may surge to 93-100\% by 2020.Branches of banks have increased from 48636 March end 2012 to 52,480 in march end 2013 and they are expected to increase due to financial inclusion in rural areas and tier III and tier IV cities. The problem of retirement is making way for entry level and lateral recruitments in PSU banks. Due to new players coming in the chance of poaching is also expected. [3]

A comparative study was carried out by Boston consultancy group (BCG) in 2012 which mainly focussed on the type of job, turnover rates and staff level which are affected by the turnover. The findings of the report are that private sector banks including ICICI and HDFC are mostly focussed on sales jobs and are hiring contract workers. These contract workers are showing a turnover of $180 \%$ every year. This is leading to customer dissatisfaction and customer keeps on shifting bankers due to the previous employee. Thus banks are unable to create a healthy customer base. In PSU banks such problems are not persisting at junior level jobs and turnover is around $12 \%$ but as entry level executives reach middle level they quit the jobs for better opportunities amounting to a turnover which is much higher than $12 \%$. The bank has spent a lot on training and recruitment to groom the junior employees for middle level jobs. Thus both types of banks are not untouched with turnover. [4]

According to Kelly services, a Delhi based recruitment firm, once the new banking licences are cleared, the financial services industry is likely to witness a significant surge in recruitment activity so much so that attrition rates are expected to hover around 18 per cent in 2014. [5]

After studying these reports and articles it can be summarized that banking sector in India is going for expansion and would give more employment to the country in next five years due to new banks coming in and new post created due to advancement in IT infrastructure in banking, financial inclusion leading to rural advancement. With this greener pasture many problems are also surfacing for the existing or upcoming banks like-

1. When more banking jobs are available the employees are getting wider choices to switch affecting their current employers.

2. The bargaining power of the employee would increase in due course. The employees would weigh many factors before joining the bank- compensation, job profile, HR policies, motivation etc.

Thus a framework is needed where banks can be brought at par with each other and a congenial working atmosphere for all players of banks can be created.

Operational definition of concepts:

- Turnover:-It is the ratio of the number of organizational members who have left during the period being considered divided by the average number of people in that organization during the period.

- HR policy:-Human resource policies are the formal rules and guidelines that businesses put in place to hire, train, assess, and reward the members of their workforce. These policies, when organized and disseminated in an easily used form, can serve to pre-empt many misunderstandings between employees and employers about their rights and obligations in the business place.

- Attrition:-a gradual reduction in work force without firing of personnel, as when workers resign or retire and are not replaced.

- Affective organizational commitment:-Affective organizational commitment refers to the employee's emotional attachment to, identification with, and involvement in the organization. Employees with a strong affective commitment continue employment with the organization because they want to do so (Meyer \& Allen, 1997: 11)

\section{Literature Review}

Sachdeva \& Kumar, (2011) carried out a study in the banks of North India turnover intentions of employees in relation to work motivation level the dimensions of motivation were- need for personal growth, need for achievement, need for self control, need for monetary gains, need for nonfinancial gains, need for autonomy \& self actualization, need for social affiliation \& conformity and overall work motivation. The result of study was the dimensions of work motivation are not significant predictors of turnover intentions. [6]

Shukla \& Sinha, (2013) performed a study on leading banks in semi urban and urban areas of India .The following factors were studied -work environment, job stress, compensation, employee relationship with management and career growth as factors influencing turnover. The result was job satisfaction and work environment influenced employee turnover. [7] Benz, (2010) carried out a study on faculty turnover of North Dakota State University. On exploration the reasons of exit were studied as controllable and uncontrollable factors. The factors studied were campus climate, lack of advancement or professional opportunities, position requirement challenges, weather or geographical location, family reasons and salary. The outcome was controllable factor i.e. campus climate which had gender difference as subfactor.The respondents were mostly 
female. The conclusion was to retain employees' controllable factors to be prioritized. [8] Sreerekha \& Kamalanabhan, (2013) Studied on ITES/BPO sector in India. Here the influence of organizational commitment is studied on turnover intentions of BPO/ITES sector employees. Organizational commitment is constitution of 3 components-job satisfaction, perceived organizational justice, and perceived organizational support. The study emphasizes on adoption of behaviour by HR practitioners which will improve job satisfaction and performance which will discourage employees to move to better opportunities. [9] Dwomoh \& Krankye,(2012) performed a study on banking employees of Ghana . The result was that labour turnover impacted performance of the bank and high turnover resulted in increased customer complaints [10] Radha, (2014) studied the impact of better HR practices in banks resulted in less turnover resulting in better customer satisfaction. [11] Saxena \& Monika, (2010) studied that clash in organizational culture and new employee leads to low retention or exit of employee. The cultural difference fall in these categories-intergroup conflict, ego clashes, identity, communication problem, HR problems. [12] Goyal and Joshi, (2012) concluded in their paper that human factors and their retention in the organization is a challenge for banking industry and the need for revamp of policies and strategies are needed to compete with global banks.[13] Tiamiyu \& Disner, (2009) performed a study on internal Auditors which revealed that availability of alternative job opportunities are major contributors in voluntary turnover. Job satisfaction and organizational commitment has little role in labour turnover. [14] Foong-ming, T, (2008) carried a study on knowledge workers suggests that career orientation of knowledge workers should be regained as part of HR policies to form a solid employee-employer relationship. The increasing demand for knowledge workers has added bargaining power to knowledge-intensive organizations and in order to hold the employees to the organization HR policies and practices that enhance personal growth and motivate the workforce is needed. [15] Mitchell et al. (2001) developed the theory of job embeddedness to explain why employees stay in their organizations. Job embeddedness can be described as a "web" of constraining forces that cause an individual to become "stuck" in different aspects of one's life, such as a job or one's family. The first of situational dimensions is links, which is "the extent to which people have links to other people or activities". The second dimension, fit, is "the extent to which their jobs and communities are similar to or fit with the other aspects in their life spaces". The third factor is sacrifice, which is "the ease with which links can be broken what they would give up if they left, especially if they had to physically move to other cities or homes" Thus, with the three factors encompassing what makes employees embedded both on- and off-the-job.[16]

Meeusen, (2011) conducted a study on dutch nurses, in which it was concluded that turnover is due to stress and burnout. The stress can be reduced by job satisfaction and burnout can be reduced by proper selection of the person on the basis of personality.[17] Oluwayemi \& Victor(2012) carried out a study in manufacturing organization, in Nigeria. The main focus was on human resource practices and its impact on involuntary labour turnover.Here, the human resource practice and turnover was studied on two dimensions of business cyclesBoom and recession. The involuntary labour turnover was more prominent in recession due to harsh HR practices like cost cutting, competition etc.The labour turnover was less in boom due to employee friendly HR practices.[18] Norsyamimi(2012)carried a study on malaysian industriesto understand the relation between labour turnover and job characteristics(skill variety, task identity and feedback) and transactional leadership style(contingent rewards, management by exception passive). The result showed significant correlation of job charcteristics and transactional leadership over labour turnover.[19]

Jeen (2014) studied turnover in retail stores in India and found that motivation,and better incentives had insignificant impact on reducing turnover. Te study also suggested that turnover was impacted by QWL, career growth, working hours, personal/family reasons, and relation with internal co - worker, welfare, working condition, and salary.[20] Clausen (2009) studied the relation ship between affective organizational commitment and turnover and long term absence from job. The result was that the affective organizational commitment and turnover were associated. [21]

\section{Methodology}

This review was performed by searching and reviewing the articles,theses and reports published in different print and online journals and books largely between 2001 and 2014 .The key words used in the search included employee turnover, attrition, retention,banks, performance, organizational commitment,HR practices. Scope of the studies reviewed in this article is limited to the factors responsible for employee turnover .

\section{Conclusion}

Through the literature review it can be concluded that labour turnover was studied on various factors like- customer complaints and satisfaction, personal growth, achievement, self control, compensation or monetary growth, self actualization, work motivation, social affiliation, organizational climate, culture clash, availability of better jobs, stress, burnout, job embeddedness, job characteristic, transactional leadership, business cycle, affective organizational commitment, quality of work life, non financial gains, career growth, working hours, family reasons, welfare, working conditions, position requirement challenge, lack of 
advancement, and so on. Two researchers Goyal and Foong-ming have suggested in their studies that HR policy should be taken to study turnover.

HR policy is the face of any organization. These are published and known to all employees. When an organization comes for hiring even at the campus they reveal HR policies to prospective candidates. Now days even on the company websites HR manuals are kept for employee reference. It has combination of many factors like-compensation, personal growth, Quality of work life, welfare, family welfare, recreation, monetary and non-monetary benefits, work life balance, post retirement care and so on. If we combine most of them to get a HR policy and study its impact on turnover it will be useful for the companies facing high turnover or high competition. Most of the factors which were mentioned are mostly experienced by the employee and can be called as intangible factors like-motivation, job embeddedness etc. If a proper HR manual is developed stating the tangible and intangible factors it can convince the employee to stay on. The employee would be more secure with written terms and conditions. Thus if impact of HR policy is studied on turnover the banks can improve the working conditions of the employee and very well make employee friendly policies and reduce the turnover.

\section{Expected Outcome}

The proposed research will lead to understand the relationship between HR policies and voluntary turnover in Indian banks. From this research it is anticipated that if HR policies have significant impact on turnover then a framework can be developed in which Human resource policies can be made an important for organizations to curb turnover problems.

\section{References}

[1]. Biswas, S. (2013, June 7).Attrition in India to top world charts in 2013; one in four employees to change jobs. ET Bureau.Retrieved May 17,2014, from http://articles.economictimes .indiatimes.com/2013-06-07/news/39815456_1_three-employees-indianemployees-attrition.

[2]. PTI.(2014,February 9). Banking sector may create 20 lakh new jobs in next 5-10 years: Experts.Retrieved May 17,2014, from http://www.thehindubusinessline.com/economy/banking-sector-may-create-20-lakh-new-jobs-in-next-510-yearsexperts/article5670424.ece

[3]. The Telegraph.(2013,December 2).PSU banks stare at staff crisis.Retreived April 17, 2014 from http://www.telegraphindia.com/1131202/jsp/business/story_17633477.jsp\#.U4YgXPm Sz3i

[4]. Shetty, M. (2012,Sep 3).New private banks see seven out of ten sales offices quit each year .Retrieved April 17,2014 from http://timesofindia.indiatimes.com/business/india-business/New-private-banks-see-seven-out-of-ten-sales-offices-quit-eachyear/articleshow /16237591.cms

[5]. Press trust of India (2014,February 13). Why banking sector expansion may increase attrition.Retrieved May 17, 2014, from http://profit.ndtv.com/news/industries/article-why-banking-sector-expansion-may-increase-attrition-380465

[6]. Sachdeva ,G.\& Kumar,N.(2011,June).Turnover intentions in relation to work motivation of banking employees.Retrieved April ,2014 from htttp://www.euroasiapub.org/ijrfm/june 2011/10.pdf

[7]. Shukla,S.\& Sinha,A.(2013,June). Employee turnover in banking sector: Empirical evidence Retrieved April 9,2014 from http://www.iosrjournals.org/iosr-jhss/papers/Vol11-issue5/J01155761.pdf

[8]. Benz,R.(2010,November). NDSU faculty turnover study. Retrieved May 3,2014 from http:// www.ndsu.edu/fileadmin/forward/documents/Benz_NDSU_Faculty_Turnover_Study.pdf

[9]. Sreerekha,K.R.\& Kamalanabhan,T.J.(2013,February). Employee turnover in banking sector: Empirical evidence. Retrieved April 2014 from http://www.ametjournal.com/attachment/ ENCORE\%20-\%20ARTICLES\%20-\%202013.pdf

[10]. Dowmoh,G.\&K.R.\& Korankye,T.(2012).Labour turnover and its impact on performance of banks in ghana.Retrieved April 9,2014 from http://www.iiste.org/Journals/index.php/EJBM/article/viewFile/1828/1781

[11]. Radha,T.J.(2014,April). Impact of human resources management practices on customer satisfaction in select public and private sector banks in thanjavur district of tamilnadu Retrieved April 9,2014 from http://www.isrj.net/Article.aspx?ArticleID=4493

[12]. Monika,K.\& Saxena,N.(2010).Organizational culture and its impact on employee retention.Retrieved May 25,2014 from http://www.anmconsultants.com/ organizational-culture-and- its-impact-employee-retention

[13]. Goyal,K.A.\& Joshi,V.(2012). Indian Banking Industry: Challenges And Opportunities Retrieved March 3,2014 from www.cscjournals.org/csc/manuscript/Journals/IJBRM/.../IJBRM-64.pdf

[14]. Tiamiyu,L.\& Disner,J.(2009,March). A study of voluntary external turnover of internal auditors. Retrieved March 12,2014 from https://na.theiia.org/iiarf/Public\%20documents/A\%20Study\%20of\%20the\%20Voluntary\%20External\%20Turnover\%20of\%20Intern a1\%20Auditors\%20-\%20St.\%20Louis.pdf

[15]. Foong-ming, Tan.(2008)Linking Career Development Practices to Turnover Intention: The Mediator of Perceived Organizational Support .retrived May 20,2014 from http://www.scientificjournals.org/ journals2008/articles/1289.pdf

[16]. Mitchell,T.R.,Holtom.B.C.,Lee,T.W.,Sablynski,C.J.\& Erez,M.(2001).Why people stay: Using job embeddedness to predict voluntary turnover. Retrieved May 20,2014 from doi=10.1.1.318.8054

[17]. Meeusen,V.C.H.,(2010,December).Risk factors for job turnover among Dutch nurse anaesthetists Retrieved April 9,2014 from http://dspace.library.uu.nl/bitstream/handle /1874/188553/meeusen.pdf?sequence=2

[18]. Oluwayemi,O.B., \& Victor,A.G.(2012,December). Astudy of human resources management practices and labour turnover in the manufacturing organisations in Lagos, Nigeria Retrieved April 9,2014 from http://www.aijssnet.com/journals/ Vol_2_No_6_August_2013/10.pdf

[19]. Norsyamimi Binti,M.N.,(2012,march).turnover intention: an examination of job characteristics and transactional leadership style among operators in electrical and electronics sub-sector Retrieved May 9,2014 from etd.uum.edu.my/3415/3/NIK_NORSYAMIMI_MD_NOR.pdf

[20]. Jeen ,S.B.D.,(2014,March). A study on attrition - Turnover intentions in retail industry retrieved April 9,2014 from http://ijbarr.com/downloads/2014/vol1-issue3/10.pdf.

[21]. Clausen,T.(2009). Psychosocial work characteristics,positive work-related states, and labour market outcomes Retrieved May 9,2014 from http://www.arbejdsmiljoforskning.dk/ /media/Boeger-og-rapporter/phd-afhandling-thomas-clausen.pdf 